\title{
Disrupted identities and forced nomads: A post-disaster legacy of neocolonialism in the island of Barbuda, Lesser Antilles
}

\author{
Sophia Perdikaris \\ University of Nebraska, Lincoln, USA \\ sperdikaris2@unl.edu (corresponding author) \\ Rebecca Boger \\ Brooklyn College, City University of New York (CUNY), USA \\ rboger@brooklyn.cuny.edu
}

\section{Edith Gonzalez}

The Graduate Center, City University of New York (CUNY), USA

edithgs03@yahoo.com

\author{
Emira Ibrahimpašić \\ University of Nebraska, Lincoln, USA \\ emira@unl.edu
}

\section{Jennifer D. Adams}

University of Calgary, Canada

jennifer.adamsl@ucalgary.ca

\begin{abstract}
In the aftermath of the forced evacuation of the island of Barbuda due to Hurricane Irma, the Barbudan people have experienced an exile and return to a 'new' geographical, political, and economic context, albeit on the same island. With the specter of climate change and the potential impacts on island communities and nations, we use Barbuda, sister island of Antigua in the Lesser Antilles, to examine the trajectory of nomadic identities as they navigate changes that threaten contemporary land relationships and culture. Since its first permanent settlement in the 17th Century, the island geography of Barbuda has been fundamental to Barbudan identity and provided continuity into modern Barbudan culture. The breaking down of this close relationship with the land and the introduction of a tourism monoculture reduces Barbuda's ability to respond to crises such as hurricanes and pandemics. In the challenge of a post-disaster economic context, we will address the conditions pushing Barbudans towards a nomadic identity. We will discuss the nomadic in terms of forced exile and subsequent return to an island changed both by a severe weather event and subsequent policy that is disruptive to Barbudan identity, sovereignty, and way of life.
\end{abstract}

Keywords: Barbuda, capitalism, Caribbean, disasters, Indigenous, islands, land tenure, nomadic identity https://doi.org/10.24043/isj.130 • Received April 2020, accepted September 2020

(C) 2020-Institute of Island Studies, University of Prince Edward Island, Canada. 


\section{Introduction}

In this article, we examine the impacts of climate change and how these affect island communities and identities in the small island of Barbuda in the Lesser Antilles. Employing a long-term perspective, from the $17^{\text {th }}$ Century to today, we look at relationships between Barbudans and their land, extending May Joseph's (1999) notion of 'nomadic identity' to include those who are forcibly displaced and eventually return.

Since pre-colonial times, the peoples who have shaped the Caribbean have had to recreate notions of home in new ecological and geographical places. This has been characterized by notions of mobilities, diasporas and nomadism. Although much of this was accompanied by the physical and psychological violence of displacement, enslavement and genocide, Caribbean peoples' own agentic actions have also transformed their lives and the world. The Caribbean, as a region, has been in a constant state of making and remaking and has neither a boundary nor a center (Benitez-Rojo, 1996). The notion of 'diaspora' has been used to describe this aspect of Caribbean life. Stuart Hall (2014, p. 235) notes, "Diaspora identities are those which are constantly producing and reproducing themselves anew, through transformation and difference." Thus, migrations and immigrations along with the key ability to adapt and transform new places of inhabitation while still maintaining an identity and connection to the conceptual space of 'home' is a consistent feature of Caribbean culture and diaspora. Notions of home and belonging can be further extended by Joseph's (1999) concept of nomadic identities, which describes the multilayered relationship between national identity, citizenship and belonging or home and how "people have lived through cataclysmic dislocations, from the colonial to nationalist then postcolonial state, to transnationally situated communities." This is further complicated by connections to place and land, which in the case of nomads, are often disrupted by "seismic changes," that prevent either returning home or cause the return to a radically transformed 'home'. In the contemporary Caribbean, many find themselves migrating multiple times in a lifetime, "twice-diasporized" (Hall, 2014). Such migrations are usually voluntary but at other times involve displacement by seismic changes in which "the correlation between national identity and country of citizenship have been shattered irrevocably" (Joseph, 1999). With the vulnerability of islands to the negative effects of climate change, displacement will become an increasing reality, raising complicated questions about national identity, belonging and home, especially for Barbudans whose identities are deeply rooted in place.

In the case of Barbuda, there was a forced exile of Barbudans to the hegemonic sister island of Antigua due to the unprecedented mid-Atlantic hurricane season of 2017. Barbudans became nomadic agents within their region and home. Upon returning to Barbuda, they faced a space that was forever transformed both by the storm and politics that disrupted their historical connection to the land (Boger \& Perdikaris, 2019). This return to a geographically, physically, materially, and political transformed landscape, marked by contestation, has truncated Barbudan agency and corresponding identity as tied to the land. This raises questions around how people with nomadic identities regain a sense of agency in a transformed place. Aligned with the theme of nomadic identities, we will in this paper address the tensions that arise when a forced nomadic identity confronts a post-disaster economic and political context in which hegemonic political forces in Antigua combine with powerful international land developers to undermine Barbudan connections to the land-to the land that had long been "the island no one owns" (Gonzalez \& Gurian, 2020). 
To examine these and other questions of history, identity and belonging, we have organized this paper so as to first provide the historical context of Barbudan land practices and identity up to the time of Hurricane Irma. We then discuss the rapid unfolding of events in the aftermath of the hurricane's destruction and how these impact Barbudan identity. Lastly, we explore the notion of indigeneity in relation to Barbudans' position in a colonial/postcolonial context vis-á-vis issues of land relationships, local ecological knowledge, and contemporary issues such as climate change.

The methodologies used here come from the authors' various disciplines, including anthropology, archaeology, geography, education, and environmental sciences. This paper is a synthesis of 15 years of fieldwork, and the primary data is reflected in the referenced publications. The authors, while based at different academic institutions in the United States and Canada, work through the Barbuda Research Complex (BRC), a non-governmental organization (NGO) operating in Barbuda. BRC is committed to the preservation and conservation of heritage and environment through education initiatives bringing together local stakeholders in collaborative ventures with interdisciplinary international scholars (Perdikaris et al, 2013). We were working on Barbuda in collaboration with Barbudans and Barbudan experts for over ten years before Hurricane Irma hit in 2017 and have been actively conducting research since Irma. Our unique position allows us to perform informed and indepth comparisons before and after the catastrophic event. Our work applies a long-term human-nature interactions - human ecodynamics - approach, in which we examine the unfolding of identity and agency through the legacy of settler colonialism and more recent developments of disaster capitalism. This then sets the stage for how Barbudan identity is responding to socioeconomic forces following a catastrophic event that has the potential to transform or even eliminate a unique Barbudan identity since the relationship to land, as with other Indigenous peoples, is being forcibly threatened. Our data come from a variety of sources including primary data through field work, participant observation, recorded oral histories, informal interviews, video documentaries, review of peer-reviewed and grey literature, archival material, news reports, and social media.

\section{Historically situating Barbudan identity in a settler colonialism context}

In order to better understand the situation on Barbuda and the relationship between Barbuda and Antigua, it is necessary to frame the historical context during the colonial period. The islands of Antigua and Barbuda became an English colony in 1632. As elsewhere in the Caribbean, captive Africans were brought in as a labor force for sugar production. In Antigua, sugar was introduced as the main cash crop by two different sources. The Willoughby, Martin and Byam families brought sugar and enslaved labor to Antigua when they fled from Surinam. This was to avoid loss of property (land and enslaved Africans) as Surinam reverted to Dutch control in the 1660s (Tweedy, 1981). The second source was Colonel Christopher Codrington, son of a Barbados sugar planter, who immigrated to Antigua in 1674, when he was given leave by the Crown to expand the centrally located plantation called Betty's Hope. Codrington began following the Barbados methods of cultivating sugar. All were interested in the favorable tropical climate, cheap labor, and fuel for the boileries in Antigua. The Codrington family became the major estate holder on the island of Antigua as they acquired neighboring sugar plantations-either the management rights or through outright 
ownership - throughout the $17^{\text {th }}$ and $18^{\text {th }}$ Centuries. Codrington had learned from his tenure in Barbados, as was the prevailing wisdom, that once a sugar estate was established, the family could return to England, leaving the estate in the care of a manager (Codrington Family Papers, 1668, 1785).

By the time Codrington emigrated to Antigua, Barbados land was entirely under sugar cane production, and there was no land left to grow provisioning crops such as squash, potato, and maize. Throughout the $17^{\text {th }}$ Century, most of the food in the English Caribbean colonies was imported from England, Ireland and North America, therefore, it became necessary to safeguard against the interruption of supplies from Europe and North America in times of war or poor weather. The Codringtons leased Barbuda with the specific intention of using it as a provisioning ground for the Antiguan estates (Dunn, 1972). Throughout the $17^{\text {th }}$ and $18^{\text {th }}$ Centuries, Barbuda became a place of agricultural experimentation. While sugar continued to be the staple commodity and chief agricultural business of Antigua, maize, guinea corn, yams, sweet potatoes, eddoes, arrow-root, cassava, pumpkins, squash, okra, and a great variety of leguminous plants were introduced to Barbuda, along with turtles, turkeys, chickens, fallow deer, horses, sheep and other cattle. By 1780, more than 300 enslaved people lived and worked on Barbuda, growing provisions, fishing, and tending cattle (Gonzalez-Scollard, 2008; Potter, 2011; Potter \& Sluyter, 2010; Sluyter, 2012; Tweedy, 1981).

The replication of the English estate model — with its strict social hierarchy—created a society with extreme constraints placed on the movements of the captive laborers and devastated the environment of Antigua. Antigua had, at best, seasonal watercourses, but no springs or other sources of fresh water besides rain. As the surveyor M. Bowen notes on his 1747 map, "Antigua is a fine island tho it has not one single spring of water in it, So that in times of drouth when all their ponds are dry and their cisterns are almost empty they are obliged to fetch their freshwater from Montserrat in times of war, or in times of peace, from Guadeloupe, a neighboring French Island" (Bowen, 1747). This made Barbuda even more important as Barbuda was the closest source of fresh water to Antigua and under the complete control of the Codrington family. Although Barbuda has a semi-arid climate, it is fortunate to have a fresh to slightly brackish aquifer system (Boger et al, 2014). During times of drought, other planters would need to travel farther and at greater cost to supply water to their estates while the Codringtons could easily access the water supply on Barbuda. This created an insular community on Barbuda, where the movements of people (both free and enslaved) between Barbuda and Antigua were heavily regulated to guard the precious water resources.

The historical records show that Codrington saw life on Barbuda as different from life on the sugar cane estates in Antigua. He stated, "I once flattered myself that the [numbers of] Negroes there [on Barbuda] having little work and good living would increase" (Codrington Letterbook, 1780). This is not to suggest that the enslaved on Barbuda, being spared from working in the sugar cane industrial complex, had an easy life. We know from the historical record of the widespread abuse of power by the managers on Barbuda throughout the $18^{\text {th }}$ century. What is certain, is that life on Barbuda was different. It was not lived according to the seasons of cane cultivation, and because of its isolation from other estates, its inhabitants developed a tight-knit community with its own culture, identity and annual rhythm separate and distinct from those of Antigua.

Slavery ended in Antigua and Barbuda in 1834. Because the entire island of Barbuda had been held under one land grant, the community continued the practice of autonomous 
cultivation on communal land in post-emancipation times. In agricultural societies with individual hereditary ownership of land, as the heirs increase over the generations, land gets subdivided until individual plots can no longer sustain the inhabitants. Instead, Barbuda practiced a communal ownership of land, where the land was never subdivided, but rather all Barbuda citizens shared equally in the ownership of land and had access to it for individual cultivation under the authority of local government (Berleant-Schiller, 1977, 1978; Tweedy, 1981). Up to recent times, this system protected the land from being sold to interests outside of Barbuda and preserved the island's cultural heritage (Potter, 2011).

\section{Developing land-based identities and practices during and after settler colonialism}

Over the years before and after emancipation, Barbudans developed a complex, land-based ecological knowledge that helped them adapt to the cycles of long droughts that affect the island. Barbudans successfully navigated these droughts by largely abandoning commercial cultivation during dry years and expanding stock-keeping, in essence creating a complex herding ecology to adapt to the annual rainfall variation (Berleant-Schiller, 1983). Barbudans dug a network of wells to take advantage of the aquifers and the natural springs that occur on Barbuda and not Antigua. Many of the wells had one or more troughs attached of varying sizes and heights to provide water to different livestock (e.g., cattle, goats, sheep). The wells and troughs were enclosed by a limestone wall with a gate. Within the walls there was a smaller walled-in area to herd the livestock into pens. During dry periods, livestock would assemble at the wells, drawn particularly to the watering trough where Barbudans would pen the cattle so that they could be tended more intensively. During wet periods, the communal land tenure allowed livestock to forage during certain seasons to breed unrestricted, and drink freely from the wells and sinkholes where water collected. When needed, Barbudans would round them up for butchering and export. It was also during wet years that Barbudans resumed crop production and so would enclose fields with fencing to protect them from livestock (Boger et al, 2014; Sluyter, 2012). Berleant-Schiller (1983, p. 87) writes of this symbiotic relationship: "Land use and tenure together have preserved the community from the hazards of drought and domination." This intimate knowledge of the land and use of the land became essential in the formation of a collective Barbudan identity. In fact, several attempts to impose different land practices, including privatization of land plots, failed after emancipation and into the $20^{\text {th }}$ Century (Berleant-Schiller, 1978; Lowenthal \& Clark, 1980). These were very different from concurrent developments in neighboring Antigua (Look, Friedman, \& Godbout, 2019).

With the common land tenure, the island was divided into different areas: most people lived in Codrington next to the lagoon, and other areas were used for agriculture, hunting or foraging wild species. While not deploying legally defined land use zoning, as is done in many societies today, Barbudans acknowledge and adhere to unwritten land use practices throughout the island. Marine environments produce an abundance of protein year-round (e.g., conch, lobster, and fish). Through their subsistence livelihoods, Barbudans developed a close connection to the land (and sea) to meet their needs. Today, Barbuda's landscape contains extensive forests, beaches, and coral reefs that have not been transformed by sugar plantations or $20^{\text {th }}$ Century large-scale tourism. While plant and animal species composition have changed from pre-colonial times, the island sustains an abundance of species, including 
several that are rare or endangered (Bowen et al, 2016; Harris, 1965; Zarnoch, 2020). Colonial and post-colonial Barbudans have transformed the landscape as did the Archaic Age (c.3000-500 BC) and Ceramic Age (c. 500 BC - AD 1500) peoples who previously inhabited the island (Bain et al, 2018; Burn et al, 2061; Grouard, Perdikaris, \& Debue, 2013; Grouard, Perdikaris, \& Rodrigues, 2019; Perdikaris et al, 2013).

Barbuda's communal land ownership is passed down through generations and is central to Barbudan identity. Enacted in 2008, the Barbuda Land Act of 2007 codified communal ownership by stating "all land in Barbuda is owned in common by the people of Barbuda" and required major developments over XCD $\$ 5.4$ million to be approved through majority vote of the elected Barbuda Council (Antigua and Barbuda, 2008). The 2016 amendment to the Barbuda Land Act (Antigua and Barbuda, 2016) increased the definition of major development to a cost in excess of XCD $\$ 40$ million.

In 2017, Hurricane Irma caused disruption in daily life, destroyed property, ecology and environment. Barbudans were forced off the island for the first time in 400 years. This forced movement allowed the government of Antigua and Barbuda to manipulate the terms of return and politicized recovery. This resulted in a 'disasterscape', defined as a 'megadisaster' "with searing images, loss of life and property, and mushrooming fiscal and economic impacts" (McQuaid, 2011). With many Barbudans lacking the capital to rebuild, this disasterscape created a space in which pleading for quick repair and relief, the communal land became a commodity that could be sold, politicized and corrupted (Adams, Fortwangler, \& Sewer, 2017). The amendment to the Barbuda Land Act in 2017 (Antigua and Barbuda, 2017) initiated the repeal of the communally owned land, opening the door for private land ownership and larger-scale tourism development (Boger, Perdikaris, \& Rivera-Collazo, 2019; Perdikaris \& Hejtmanek, 2020).

\section{Hurricane Irma Strikes}

Even before Hurricane Irma hit in 2017, Barbuda, like other Caribbean islands, faced many challenges-food insecurity, coastal erosion, storm surges, inadequate water quality and quantity, high poverty and unemployment levels, and limited economic opportunities that result in a 'brain drain' of young, educated people migrating off the island. Farming was in decline due to the loss of local traditional ecological knowledge, and lack of interest especially amongst the younger generation (Boger et al, 2016). Fishing, a particularly important subsistence practice for Barbuda, could no longer sustain the population, partly due to the bleaching and dying of reefs throughout the Caribbean that contributes to the depletion of nearshore fish stocks. These interconnected challenges intensify and become increasingly urgent as sea level rises and climatic changes cause fluctuations in temperature and precipitation patterns, including the intensity and frequency of storm events (Christensen et al, 2013). This was the context of the island when the unprecedented storm struck in Barbuda's historical record, leaving the island vulnerable to the rapid changes that occurred immediately after the disaster.

Category 5 mega-storm Hurricane Irma hit Barbuda in early September 2017, destroying much of the island's landscape and infrastructure; the physical damage was widely publicized (Boger, Perdikaris, \& Rivera-Colazo, 2019). In the aftermath of the storm, however, multinational developers and the central government in Antigua-which has 
jurisdiction over the Barbudan governing council—inadvertently perpetuated the devastation by focusing on tourist ventures rather than local recovery (Boger \& Perdikaris, 2019). Prime Minister Gaston Browne tried to impose Antigua's development strategy on Barbuda. This was in violation of the 2007 Barbuda Land Act, which states that "all land in Barbuda shall be owned in common by the people of Barbuda" and "no land in Barbuda shall be sold" (Antigua and Barbuda, 2008). Although Barbuda is part of the nation of Antigua and Barbuda, Antigua's economy, like most of the Caribbean, is fueled by large-scale tourism. Barbuda's governing council sets itself apart by being very selective about which development projects are allowed on the island (Perdikaris \& Hejmanek, 2020). However, after the hurricane, Barbuda was compelled to rely on the larger Antiguan government as well as international funding for recovery, rendering it less autonomous in following its own path of development. This was further exacerbated by the repeal of the Barbuda Land Act on May 3, 2018, allowing the Antiguan government to sell land without having to consult Barbudans or the Barbudan Council (Gonzales, 2020). The international press claimed that the foreign investors seeking to embark on tourism development post-Irma were taking advantage (Klein \& Brown, 2018) of traumatized and vulnerable people under the guise of acting as "benevolent benefactors" (Associated Press, 2017) without an understanding of what constitutes local culture, ethnicity, and tradition. This increased the existing tension between Antigua and Barbuda.

The hurricane intensified the severance of Barbudan identity from the land as disaster capitalism took immediate hold in post-Irma Barbuda. Disaster capitalism describes how wealthy elites exploit crises, such as major natural disasters or pandemics, to reap profits and deepen inequality, while affected populations are still in shock (Klein, 2007; Klein \& Peet, 2008). Barbudans were particularly vulnerable because they were forcibly evacuated to Antigua by the military and not allowed to return for several weeks - many Barbudans were kept away from the island for up to four months. The Antiguan government justified this by citing health concerns, indicating that Barbudans would be more vulnerable to disease on the island after the hurricane and could infect others. While Barbudans were kept away from their homes and land, the military, foreign NGOs and the press were allowed regulated but unrestricted visits, including long-term stays (Boger \& Perdikaris, 2019; Boger, Perdikaris, \& Rivera-Collazo, 2019).

Undoubtedly, the destruction in Barbuda was extensive, particularly to agriculture and built infrastructure, with a death toll of one child. The majority of vegetation was completely defoliated, inundated by saltwater, or broken and uprooted. The absence of people (who remained displaced) triggered further destruction as damaged properties were left to rot in the rain and sun, destroying family memories and belongings. Family dogs roamed in hungry and feral packs, and many were put down by the military, while livestock was left to fend for themselves with meager vegetation (Boger \& Perdikaris, 2019; Boger, Perdikaris \& RiveraCollazo, 2019). The press describing post-Irma Barbuda as "deserted" and highlighting abandoned pets and animals further painted a picture of "paradise lost," an abandoned tropical landscape ripe for occupation and development by disaster capitalists (Adams, Fortwangler, \& Sewer, 2017).

Two years after Irma hit, the people living in Codrington are still recovering with onehalf to two-thirds of the residents having returned to Barbuda. With Prime Minister Brown's repeal of the Barbuda Land Act, attempts to privatize the land have opened the doors to international developers who have successfully gained hold of large areas around the island 
and now pay taxes to Antigua rather than to the Barbudan local government. Gated communities, hotels, marinas, a large airport, and golf courses are being proposed and for many developments, and work has already begun at several places along the Caribbean side of the island. One site, Palmetto Point, is located within the Ramsar protected wetland site that includes Palmetto Point, Codrington Lagoon and mangrove forests to the north (Joseph, 2020a, 2020b). The Ramsar Convention recognizes the importance of these wetlands and promotes the active involvement of Indigenous people and local communities in the management and protection of these biodiversity hotspots (Oviedo \& Kenza Ali, 2018). This is a grave loss of Barbudan agency over the land. Furthermore, as Barbudan identity is tied both to the land and the traditional ecological knowledge developed over generations, the loss of agency over the land could also have dire consequences for the natural and agricultural environment.

\section{Disruption of land: Imposing nomadic identities}

With the entire population of Barbuda having been evacuated to Antigua in the wake of Hurricane Irma, Barbudans, who assumed a nomadic identity associated with a forced exile and return, now confront new layers of complexity and strain on individual and collective identity and community relationships. They have returned to the same-albeit radically transformed-land. This causes them to experience the multidimensional stress of displaced people that leads to increased rates of morbidity and mortality. The associated psychological stress is expressed through trauma, guilt, grief and anxiety, and finally, sociocultural stress which occurs through broken social networks, economic deprivation, and loss of power (Crate \& Nuttall, 2009, p. 129). In addition to these psychological stressors, dislocated people experience the material and emotional stress of having to rebuild their homes, relationships, and communities, all of which takes a serious toll on people's ability to adjust to the new way of life. These disruptions have long-term effects on their sense of belonging and meaningful purpose for all their efforts. The reconfiguration of their traditional ways of life, social networks, kin relationships and livelihoods can lead to greater impoverishment of the community (Crate \& Nuttall, 2009). The repeal of the Barbuda Land Act and the development currently underway in Barbuda will further add to the stressors as they disrupt the very basis of identity as a collective Barbudan people. Barbudans are fighting to re-establish their identities and agencies on the same land but in a vastly changed physical, material and political context.

Having a deep history of overcoming enslavement and a constant battle with Antigua for control of their land, Barbudans are relying on their strong and collective land identity to resist this loss of autonomy. Such efforts build upon the complex and strong connections that the Barbudan diaspora continues to have with the land (Potter, 2015). A local resistance movement, Barbuda Silent No More (n.d.a; n.d.b), uses social and a website to give Barbudans a voice and to keep Barbudan diaspora and others informed about the events going on there. Legal action temporarily halted construction on the airport (The Daily Observer, 2018). Barbudans, working with international lawyers, filed an injunction to expose the unlawful premise of the repeal of the Barbuda Land Act (Garden Court Chambers, 2017). The Barbuda Council has asked the Development Control Authority to stop the Peace, Love and Happiness project at Palmetto Point (Joseph, 2020a; 2020b). Actions to date have not halted the repeal of the 2017 Barbuda Land Act, nor have they stopped development. 


\section{Barbudan identity and the question of Indigeneity}

Because of the history of enslavement and violent disruption from their Indigenous lands, Africans have had to forge connections to new lands in the Americas. Because of this, there are contestations about the indigeneity of Afro-Caribbean people in settler-colonial lands. The land and its natural habitat are integral parts of their daily life, history, and identity. Thus cultural traditions and identities are intimately connected to their place (Adger, Barnett, Brown, Marshall, \& O’Brien, 2013; Adger, Barnett, Chapin, \& Ellemor, 2011; Adger et al, 2009; Kaenzig \& Piguet, 2014; Pearce, Willox, \& Smit, 2015; Wolf, Allice, \& Bell, 2013).

Although an official definition of 'Indigenous' has not been adopted by the United Nations (APF, 2013), it is recognized that Indigenous people inherit and practice unique cultures, particularly in the relationship between culture and the local environment. According to the United Nations, Indigenous people have:

- "Self-identification as Indigenous peoples at the individual level and accepted by the community as their member.

- Historical continuity with pre-colonial and/or pre-settler societies

- Strong link to territories and surrounding natural resources

- Distinct social, economic or political systems

- Distinct language, culture and beliefs

- Form non-dominant groups of society

- Resolve to maintain and reproduce their ancestral environments and systems as distinctive peoples and communities." (United Nations Permanent Forum on Indigenous Issues, n.d.)

Barbudan identity has many of these characteristics, particularly in how its cultural, political, and economic systems are intricately connected to their land and resources. While they may not call themselves Indigenous, they do consider themselves distinct in many ways from their closest neighbors in Antigua. The Barbuda Land Act was designed to allow Barbudans to maintain their culture, in part through controlling how their communal land is used. Although Barbuda has a long history of ancestral people living there (Bain et al, 2018), people were not living there in permanent communities at the onset of colonialism. Thus, the modern-day Barbudans have become the descendants of a unique group of people with a unique history and culture. As such, although they are not connected to peoples from precolonial times, the enslaved Africans and their descendants creatively integrated themselves into the island ecology. They have engaged in a process that some Caribbean scholars call 'bricolage', described as a cultural process, "a mode of interpreting and adapting existing materials to new circumstances or needs" (Knepper, 2006, p. 71). This includes adapting and integrating new species that were introduced to the island during colonialism as well as sustaining a healthy and resilient ecological system for several hundred years. For centuries, Barbudans developed strong ties to the land and place, and passed down their ecological knowledge over the generations through shared practices.

As the primary inhabitants and keepers of the island, Barbudans have a right to selfdetermination and should have control over what they have traditionally thought of as their 
own, whether it be land or resources (Dean \& Levi, 2003, p. 326). Historically, especially in North America, Indigenous people have been made nomadic through violent disruptures from their lands while settler-colonizers profited from the same lands. Today, there are numerous instances where Indigenous lands and resources have been exploited for the benefit of the whole settler nation while failing to equitably redistribute profits back to the Indigenous people. In nearly every case, these types of projects lead to further inequity and disenfranchisement. As Tsing (2005) reminds us, global capitalism is coercive and as such perpetuates "unequal collaborations." Ultimately, it is important to acknowledge that Barbudans, like many other Indigenous peoples around the world, "desire autonomy, which, in the vast majority of cases, means that they wish to exercise local control over their own affairs within the framework of the states in which they live" (Dean \& Levi, 2003, p. 331). Barbudans have a natural right and ownership over the land they inhabit, and as such must be present at the table during conversations that determine the future of their homeland.

While legal arguments may question whether Barbudans are indeed Indigenous, one cannot dispute that they are a longstanding local community and in that capacity are important for protecting biodiversity (Phillips, 2019) through a balanced interdependence between them and the local environment. Equally important is the fact that Barbudans possess what is known as traditional ecological knowledge or "a cumulative body of knowledge, practice and belief, evolving by adaptive processes and handed down through generations by cultural transmission, about the relationship of living beings (including humans) with one another and with their environment" (Usher, 2000, p. 8). As a result, local communities, along with Indigenous peoples, are recognized to be extremely important in protecting biodiversity (Oviedo \& Kenza Ali, 2018). It is also estimated that although Indigenous peoples comprise less than $5 \%$ of the global population, they protect $80 \%$ of global diversity (Raygorodetsky, 2018). A recent study by Schuster et al. (2019) demonstrates that Indigenous-managed lands are an essential repository of species in Australia, Brazil and Canada, and that this is likely representative of other regions. Barbudans can be considered part of this small group of global citizens and, as such, play a critical role in biological preservation.

In an attempt to 'catch up' with the wealthy countries of the Global North, many governments have placed economic development above the rights of Indigenous populations and in doing so have led to massive dislocation and destruction of Indigenous land, cultures, and way of life. Around the world, we see examples of Indigenous lands being exploited in the name of economic progress and prosperity. Because many Indigenous people live in remote areas that have seen little development and because many of them use traditional and noninvasive land-use methods, their land is often seen as a prime spot for 'development projects' (Dean \& Levi, 2003, p. 151). More often than not, pre-existing land rights do not mean that the land is 'secure'. This is indeed the case in Barbuda, and much like other Indigenous groups, Barbudans' land rights have been stripped in the name of progress and development. This is demonstrated in the building of a large airport destroying wetlands, prime hunting lands, and agricultural lands as well as the planned golf course and houses for tourists at Palmetto Point, which is part of a Ramsar site as described above. Many Barbudans and the Barbudan Council have agricultural properties in the Palmetto Point area. Palmetto is also where sod production and sand mining operations occur.

As a result, Indigenous people are often forced to either assimilate or are simply pushed out in the name of progress. Since so much of their identity depends on the natural landscape 
itself, the dramatic changes to the land can mean loss of their unique cultural values, practices, and traditions. The current struggles faced by Barbudans regarding development, which will force transformation of their territories and landscapes, closely resembles global processes focused on free trade and market economics as the guiding principle of progress. In a global economic order where profit trumps all other considerations, Barbudans, similar to many Indigenous people around the globe, occupy a place at the margins of political and economic decision making and are ultimately excluded from any conversation that involves their own futures (Dean \& Levi, 2003, p. 29). Various Indigenous groups that have attempted to speak out against these changes have found limited success, and their voices have often been silenced by the same governments that are supposed to represent them (Howard, 2003, p. 202).

Barbudans should recognize that, when it comes to their position as a people on the margins, it is important to pay attention to the ways in which the state is monopolizing power. Barbudans may need to follow in the footsteps of other Indigenous groups who have organized themselves by forming political parties and advocacy groups. If the disaster capitalism practices in Barbuda are to be stopped, political action is needed.

Around the globe, from the Pacific to the forests of Malaysia, Indigenous and nonIndigenous people alike are forced out of their homes by the effects of climate change. For many of these people, especially those living in island nations, culture and life are inextricable from the land, and the island that they have inhabited for multiple generations. While loss of life and material possessions as a result of natural disasters gets plenty of discussion, one area that needs more attention is the way in which natural disaster displacement affects people's identities, and the role that those identities and senses of self meaning can play in decisionmaking processes and policy regarding climate change on a local and global level.

\section{Navigating a nomadic future}

The Intergovernmental Panel on Climate Change (IPCC, 1990) states that by 2050 more than 200 million people around the globe will be forced to leave their home as a result of climate change. This estimate is frequently cited though estimates of forced migrations due to climate change are difficult to predict (Brown, 2008). Recent displacement estimates reach up to and over 1 billion while forecasts from the UN International Organizations for Migration posit that there could be between 25 million to 1 billion environmental migrants by 2050 , moving either within their countries or across borders, on a permanent or temporary basis (Bassetti, 2019). At present experts agree that making projections on climate migration are complex and multi-faceted, yet the fact remains that in 2019, 17.2 million people were displaced by disasters alone (nearly double of those displaced by conflict) (Internal Displacement Monitoring Centre, 2019).

This means that as we look to the future, more people will find themselves adopting and navigating nomadic identities. The necessity to understand what this experience entails is important in helping us better understand challenges they face if and when they return home. What is even more important is to find ways to protect those affected so that their governments or international developers do not take advantage of their situation to further their own personal agendas. Ongoing conversations regarding the relationship between climate change, displacement and identity point to the need to better understand these relationships as we develop policies and interventions designed to prevent or mitigate future 
disruptions. How different communities react to and deal with forced displacement as a result of climate change will help inform us of the impact that resettlement has on health, wellbeing, and collective responses.

Forced migration due to natural disasters exacerbated by climate change is complex and problematic and often ignores the effect that these relocations have on people's livelihoods and cultural survival. Although in 2015 the United Nations High Commissioner for Refugees (2015) partnered with the Brookings Institution to release a report that outlines best practices that ensure protection of people from disasters and environmental change, few countries have successfully implemented these suggestions. Displacement caused by a disaster is hard on any group, but especially on those groups whose ties to the land are so strong that the loss of land means the loss of their distinctive cultural identity and way of life.

Crate and Nuttall $(2009$, p. 123) point out that dislocation brought about by climate change can compound to create a "cumulative loss of meaning" and can "shake the foundation of personal worldview and identity." Natural disasters rob people of being able to live meaningful and purposeful lives they are accustomed to and can lead to people feeling "bereft of a sense of meaning and purpose in life." What is equally important is the loss of sense of place, which for many island people sits at the core of their sense of self and identity (Adams, 2013; 2014). Place is a dynamic concept that describes social areas of human interaction and social relations that helps us better understand people's identities. Basso (1996, p. xiv) argues that place, or sense of place, "partake of cultures, or shared bodies of 'local knowledge' with which persons and whole communities render their places meaningful and endow them with social importance." Place for many Indigenous peoples, including Barbudans, represents a connection to their identity, and it is how people make meanings of themselves, their position within their community and how they are "woven into the fabric of social life" (Basso, 1996, p. 34, p. 110). This sense of place allows for the creation of an 'environment of trust' in "which space, kin, relations, local communities, cosmology, and traditions are linked" (Giddens, 1990, p. 102). When place is disrupted, or taken away, then so is this 'environment of trust'. Moreover, dislocation and return can lead to "a loss of intimate human-environment relationships that not only ground and substantiate indigenous worldviews, but also work to maintain and steward local landscapes" (Crate \& Nuttall, 2009, p. 12). Ultimately, for many disaster-displaced people, loss of place can mean what Crate and Nuttall (2009, p. 117) call "removal from life," which is caused by disruption to individual and community identity and stability in place. The effects of this can be devastating and can lead to silencing, leading people to say nothing when their land and resources are misappropriated by the governing bodies. Ultimately, we will all experience the negative effects of this silencing through a loss of biodiversity and cultural practices that are critical to sustaining balance on our lands and in our seas.

\section{Nomads of return}

What is compelling in the Barbuda case is the aftermath of the 'perfect storm'. The combined forces of climate change and disaster capitalism are creating both nomadic identities and 'nomads of return' within Barbuda, corresponding with a dramatic loss of culture and in connection to their local environment. This loss of culture troubles identity and the sense of self for people whose existence was interconnected with land and place. Descendants of 
enslaved Africans are once again faced with a violent disruption from the land. Massive bulldozing has taken place for an extensive 'new airport' that destroyed protected tree species, peoples' private farmland, historic and prehistoric sites, and fallow deer and red-footed tortoise breeding grounds (Boger \& Perdikaris, 2019). The acquisition and bulldozing of most of the undeveloped Caribbean coastline of the island by numerous external developers is also destroying plants, animals, reefs and traditional landscapes. This is a theft of both land and identity, the enforced adoption of a western monetized system, a loss of local governance, and an inability to 'live from the land'. Barbudans are becoming visitors, and Barbuda is being converted into a foreign land with imported controls, regulations and norms. These are similar to the experiences of other peoples who have been displaced or who are negotiating their place, existence and borders (Mackay, DeCarvalho, Cavoukian, \& Cuthbert, 2014).

For contemporary Barbudans, the first nomadic experience was forced movement from Africa as enslaved peoples. It was marked by an emplacement in a land where their liberty and rights were taken away. After emancipation, the once enslaved were able to use their human agency and keen knowledge of the land to create a sustainable and self-sufficient society. By adopting the power symbols of the former empire (Perdikaris et al, 2018) and their deep knowledge of the land, they sealed their identity by transforming from nomads to peoples of Barbuda. However, the saga of nomadism is far from over. The joint forces of neocolonial expansionist agendas for quick profiteering by the central government in Antigua, in alliance with external sources, has started a long battle that has as its sole purpose the robbing of land from Barbudans, disallowing Barbudan identity by not allowing Barbudans any kind of separation in governance from Antigua and by pushing a neo-settler colonialism relationship with the land.

In a critical analysis of Israeli settler-colonialism, Yacobi and Tzfadia (2019, p. 2) suggest the term 'neo-settler colonialism' to express new regimes of "control, appropriation and colonization stemming from neoliberalism, privatization and new public management." These new regimes advance colonial projects through the use of neoliberal ideals. In the case of Barbuda, the method is privatization and monetization of once-communal land. Cavanaugh and Verancini (2013, p. 1) argue against use of the term neo-settler colonialism, suggesting that "settler colonialism is a resilient form that never ends" and "settlers want Indigenous people to vanish." However, the relationships between Barbuda and Antigua and, more importantly, the policy forwarded by the Prime Minister against Barbudan sovereignty, speak to a situation that is complicated by the historicity that has shaped the Caribbean as a region and the individual island nations to date. The neo-settler colonialism is somewhat 'selfimposed' by the national governments, which often have the same racial identity and history as the populations they serve but have internalized colonial logics in their policies and relationships in ways that are detrimental to regional agency.

The impact of hurricanes facilitated these external ulterior motives and allowed the Prime Minister totalitarian control over Barbuda. The Prime Minister is steadily selling the land to non-Barbudans, allowing projects that bulldoze fields, cultural heritage sites, protected forest, wetlands and breeding grounds for deer and red-footed tortoises, all symbols of Barbudan identity. The temporary traumatic displacement of Barbudans to Antigua after Irma took proud peoples of the land and reduced them to taking hand-outs as second-class citizens. Many will never be able to recover from the experience, and a multitude of Barbudans have voiced their concern about feeling like slaves in their own country all over again (Gould \& 
Lewis, 2018). Sadly, many have since passed away. This temporary displacement might become permanent as their homeland transforms into another Caribbean playground for the rich and famous. Barbudans will be forced to adopt a changed identity that renders them almost strangers in their own, traditional lands.

Barbudans might not have a big cash economy, but everyone has a home, and people do not go hungry. They hunt, gather, grow food and exchange. They have a communal savings called 'the box', where groups of people contribute funds when they get paid, and each take turns using the cumulative sum of the group for an important reason, whether it be for a medical procedure, sending a child to university or buying material for building a house. When someone has material for building, the tradesmen often build for no money but are served food and drinks as a communal act. They know that when they need help, their neighbors will do the same for them (L. Thomas, pers. comm., 2015). In a gentrified landscape where everything becomes a monetized exchange, the resident Barbudans are forced into becoming nomads seeking agency and space in a land that is no longer theirs.

\section{Forwarding an agentic nomadic identity}

Forces of nature, climate change, disaster capitalism, and the effects of a perfect storm have led to a precarious future for Barbuda and Barbudans. As they face this uncertainty, Barbudans are left to their own devices to protect their land and livelihood. One way in which Barbudans can fight the negative effects of these events is to follow the example of other Indigenous groups who have found themselves in similar situations. To avoid the silencing of their voices and their relationship to their lands, Barbudans could forge and maintain strategic alliances with Indigenous groups and organizations focused on environmental justice and sustainable development. Through these alliances, they could maintain and strengthen their agency in their advocacy for land autonomy. Because of their unique relationship to the land they inhabit, Indigenous peoples have successfully been making these alliances since the 1980s, beginning with efforts to save the Amazon. From the outset, these collaborations seemed natural because the western scientific community found that Indigenous peoples, like Barbudans, have cultural practices that value and maintain local biodiversity (Tsing, 2005, p. 159). Moreover, environmental activists found allies in Indigenous groups not only because they were willing to protect these vulnerable ecosystems, but because they were willing to share their knowledge and allow them to be used as the face of the movement. Although these alliances are an important way for Indigenous people to ensure that their voices are heard on a global scale, it doesn't mean that the relationship between the environmentalists and the Indigenous people has been without its problems (Pickerill, 2018, p. 1123). These alliances can nevertheless lead to some degree of political influence to counter government policies that threaten Barbudan livelihoods and ways of life.

As we reflect on the unique case of Barbudan experiences with indigeneity and nomadic identity, we recommend that future research on nomadic identities must involve an examination of people who, once displaced, have now returned to their homes. Moreover, forthcoming research in Barbuda must include investigation of local movements that center on social and environmental justice. An examination of the current ways in which Barbudans are ensuring that land-affirming and land-sustaining movements center on social and environmental justice makes for important future research. 
Future research in Barbuda must also examine different ways in which locals are ensuring that the holistic well-being of the collective is prioritized over the capitalistic profit of the few, who are more often than not disassociated from the land. This research would also center discussions of race, class, gender and socioeconomics vis-á-vis issues of power and use these discussions as a means to collective organizing, empowerment and resistance of the hegemonic and neoliberal forces that serve to sever people from their lands and sense of identity. In addition, future research needs to incorporate mechanisms to understand how Barbudans are resisting and advocating for Indigenous and local control over land, and whether or not they utilize a cooperative model which could ensure that local economies and infrastructure are supported (Adams, Fortswangler, \& Sewer, 2017). These investigations would help us better understand how local control of 'development' occurs and whether or not it benefits the people of Barbuda. It is important to record whether or not foreign investors are required to contribute to modernizing schools, libraries, etc. and whether or not a generous percentage of profits is returned to building and maintaining important infrastructure on the island. Similarly, an account of whether or not hotels and the hospitality industry are required to purchase from small-scale local agriculturalists will shed light on how development unfolds in Barbuda.

As scholars we know that the cooperative model can help protect agricultural and natural heritage, including unique flora and fauna, in the Caribbean. In other words, we must challenge:

our prevailing conceptions of what it means to be human in this world. Specifically, we must be human in ways that are not defined by the overrepresented logics of whiteness, neoliberalism, and predatory capitalism. It is also a call for a pedagogy or framework that allows us to critique the historical settler colonialism and contemporary settler environmentalism and centers a decolonizing approach to (re)development. (Adams, Fortwangler, \& Sewer, 2017)

Disaster capitalism and privatization of common resources is an old story, but it is one that is still ongoing. Can Barbudans subvert the paradigm, or are they nomadic peoples in the making?

\section{References}

Adams, J.D. (2014). Place and identity: Growing up bricoleur. In Tobin, K., \& Shady, A. A. (Eds). Transforming urban education: Collaborating to produce success in science, mathematics and technology education. Sense. https://doi.org/10.1007/978-94-6209-563-2 20

Adams, J.D. (2013). Theorizing a sense-of-place in a transnational community. Children, Youth and Environments, 23(3), 43-65. https://doi.org/10.7721/chilyoutenvi.23.3.0043

Adams, J.D., Fortwangler, C., \& Gibney-Sewer, H. (2017, October 19). Green islands for all?: Avoiding climate gentrification in the Caribbean. Ethnobiology. https://ethnobiology.org/forage/blog/green-islands-all-avoiding-climategentrification-caribbean

Adger, W.N., Barnett, J., Brown, K., Marshall, N., \& O'brien, K. (2013). Cultural dimensions of climate change impacts and adaptation. Nature Climate Change, 3(2), $112-$ 117. https://doi.org/10.1038/nclimate1666 
Adger, W.N., Barnett, J., Chapin III, F.S., \& Ellemor, H. (2011). This must be the place: Underrepresentation of identity and meaning in climate change decision-making. Global Environmental Politics, 11(2), 1-25. https://doi.org/10.1162/GLEP a 00051

Adger, W.N., Dessai, S., Goulden, M., Hulme, M., Lorenzoni, I., Nelson, D.R., Naess, L.O., Wolf, J., \& Wreford, A. (2009). Are there social limits to adaptation to climate change? Climatic change, 93(3-4), 335-354. https://doi.org/10.1007/s10584-008-9520-z

Antigua and Barbuda (2008). The Barbuda Land Act, 2007. Official Gazette 28(5), 1-18.

Antigua and Barbuda (2016). The Barbuda Land (Amendment) Act, 2016, No. 12 of 2016. Official Gazette, 35(58), 1-5.

Antigua and Barbuda (2017). The Barbuda Land (Amendment) Act, 2017, No. 41 of 2017. Official Gazette, 38(8), 1-11.

APF (2013). The United Nations Declaration on the Rights of Indigenous Peoples: A manual for national human rights institutions. Asia Pacific Forum of National Human Rights Institutions \& Office of the United Nations High Commissioner for Human Rights.

Associated Press (2017, September 19) Robert DeNiro asks for help restoring Barbuda after Hurricane Irma. USA Today. https://www.usatoday.com/story/life/2017/09/19/deniro-help-rebuild-barbuda-paradise-destroyed-by-irma/105777024/

Bain, A., Faucher, A.M., Kennedy, L.M., LeBlanc, A.R., Burn, M.J., Boger, R., \& Perdikaris, S. (2018). Landscape transformation during Ceramic Age and colonial occupations of Barbuda, West Indies. Environmental Archaeology, 23(1), 36-46. https://doi.org/10.1080/14614103.2017.1345115

Barbuda Silent No More (n.d.a). Barbuda Silent No More. Facebook. https://www.facebook.com/barbudasilentnomore

Barbuda Silent No More (n.d.b). Barbuda Silent No More. GlobalNPO. https://www.globalnpo.org/AG/Codrington/1447831015286008/Barbuda-SilentNo-More

Bassetti, F. (2019, May 22). Environmental migrants: Up to 1 billion by 2050. Foresight: The CMCC observatory on climate policies and futures.

https://www.climateforesight.eu/migrations-inequalities/environmental-migrants-upto-1-billion-by-2050/

Basso, K.H. (1996). Wisdom sits in places: Landscape and language among the Western Apache. University of New Mexico Press.

Benítez-Rojo, A. (1996). The repeating island: The Caribbean and the postmodern perspective. Duke University Press. https://doi.org/10.1215/9780822382058

Berleant-Schiller, R. (1977). The social and economic role of cattle in Barbuda. Geographical Review. 67(3), 299-309. https://doi.org/10.2307/213724

Berleant-Schiller, R. (1978). The failure of agricultural development in post-emancipation Barbuda: A study of social and economic continuity in a West Indian community. Boletin de Estudios Latino Americanos y del Caribe, 25, 21-36.

Berleant-Schiller, R. (1983). Grazing and gardens in Barbuda. The keeping of animals: Adaptation and social relations in livestock producing communities (pp. 73-91). Rowman \& Littlefield. 
Boger, R., \& Perdikaris, S. (2019). After Irma, disaster capitalism threatens cultural heritage in Barbuda.

NACLA.

https://nacla.org/author/Rebecca\%20Boger\%20and\%20Sophia\%20Perdikaris

Boger, R., Perdikaris, S., Potter, A.E., \& Adams, J. (2016). Sustainable resilience in Barbuda: Learning from the past and developing strategies for the future. International Journal of Environmental Sustainability, 12(4), 1-14.

Boger, R., Perdikaris, S., Potter, A.E., Mussington, J., Murphy, R., Thomas, L., Gore, C., \& Finch, D. (2014). Water resources and the historic wells of Barbuda: Tradition, heritage and hope for a sustainable future. Island Studies Journal, 9(2), 327-342.

Boger, R., Perdkaris, S., \& Rivera-Collazo, I. (2019). Cultural heritage and local ecological knowledge under threat: Two Caribbean examples from Barbuda and Puerto Rico. Journal of Anthropology and Archaeology, 7(2), 1-14. https://doi.org/10.15640/jaa.v7n2p1

Bowen, E. (1747). A complete atlas: Antigua or Antego, No. 67. Folio. William Innys.

Bowen, F., Carden, R.F., Daujat, J., Grouard, S., Miller, H., Perdikaris, S., \& Sykes, N. (2016). Dama dentition: A new tooth eruption and wear method for assessing the age of fallow deer (Dama dama). International Journal of Osteoarchaeology, 26(6), 1089-1098. https://doi.org/10.1002/oa.2523

Brown, O. (2008). Migration and climate change, 31. United Nations.

Burn, M.J., Holmes, J., Kennedy, L.M., Bain, A., Marshall, J.D., \& Perdikaris, S. (2016). A sediment-based reconstruction of Caribbean effective precipitation during the 'Little Ice Age' from Freshwater Pond, Barbuda. The Holocene, 26(8), 1237-1247. https://doi.org/10.1177/0959683616638418

Cavanagh, E., \& Veracini, L. (2013). Editors statement. Settler Colonial Studies, 3(1), 1-1. https://doi.org/10.1080/18380743.2013.768169

Christensen, J.H., Kanikicharla, K.K., Aldrian, E., An, S.I., Cavalcanti, I.F. A., De Castro, M., et al. (2013). Climate phenomena and their relevance for future regional climate change. Climate Change 2013 the Physical Science Basis: Working Group I Contribution to the Fifth Assessment Report of the Intergovernmental Panel on Climate Change (pp. 12171308). Cambridge University Press.

Codrington, W. Letterbook 1779-1782. Unpublished. James Marshall and Marie-Louise Osborn Collection, Bienecke Rare Book and Manuscript Library, Yale University.

Codrington Family Papers (1668). Grant of Barbuda (D1610 T9). Gloucestershire Regional Archives.

Codrington Family Papers (1785, September 4). W.C. to Reynolds (D1610 C14/1). Gloucestershire Regional Archives.

Crate, S.A., \& Nuttall, M. (2009). Anthropology and Climate Change: From encounters to actions. Walnut Creek.

The Daily Observer (2018, September 12). Barbuda airport injunction lifted. The Daily Observer. https://antiguaobserver.com/barbuda-airport-injunction-lifted/

Dean, B., \& Levi, J.M. (Eds.). (2003). At the risk of being heard: Identity, indigenous rights, and postcolonial states. University of Michigan Press. https://doi.org/10.3998/mpub.11605

Dunn, R. (1972). Sugar and slaves. University of North Carolina Press.

Garden Court Chambers (2017). Barbudans file injunction to expose unlawful introduction of land act changes. Garden Court Chambers. 
https://www.gardencourtchambers.co.uk/news/barbudans-file-injunction-to-exposeunlawful-introduction-of-land-act-changes

Giddens, A. (1990). The consequences of modernity. Stanford University Press.

International Displacement Monitoring Center (2019). Global report on internal displacement. International Displacement Monitoring Center. https://www.internaldisplacement.org/sites/default/files/publications/documents/2019-IDMC-GRID.pdf

Gonzalez, S., \& Gurian, S. (2020, January 31). Episode 969: The Island No One Owns. Planet Money. $\quad$ https://www.npr.org/2020/01/31/801645818/episode-969-the-island-noone-owns

Gonzalez-Scollard, E. (2008). Raising cane: Sugar, people and the environment in nineteenth-century Antigua, West Indies. City University of New York.

Gould, K.A., \& Lewis, T.L. (2018). Green gentrification and disaster capitalism in Barbuda: Barbuda has long exemplified an alternative to mainstream tourist development in the Caribbean. After Irma and Maria, that could change. NACLA Report on the Americas, 50(2), 148-153. https://doi.org/10.1080/10714839.2018.1479466

Grouard, S., Perdikaris, S., \& Debue, K. (2013). Dog burials associated with Human burials in the West Indies during the early pre-Columbian Ceramic Age (500 BC-600 AD). Anthropozoologica, 48(2), 447-465. https://doi.org/10.5252/az2013n2a17

Grouard, S., Perdikaris, S., Espindola Rodrigues, N.E., \& Quitmyer, I.R. (2019). Size estimation of pre-Columbian Caribbean fish. International Journal of Osteoarchaeology, 29(3), 452-468. https://doi.org/10.1002/oa.2782

Hall, S. (2014). Cultural identity and diaspora. In N. Mirzoeff (Ed.). Diaspora and visual culture (pp. 35-47). Routledge.

Harris, D.R. (1965). Plants, animals, and man in the outer Leeward Islands, West Indies: An ecological study of Antigua, Barbuda and Anguilla. University of California Press.

Howard, B.R. (2003). Indigenous peoples and the state: The struggle for native rights. Northern Illinois University Press.

IPCC (1990). Climate change: The IPCC Scientific Assessment. J.T. Houghton, G.J. Jenkins, \& J.J. Ephraums (eds.). Intergovernmental Panel on Climate Change.

Joseph, C. (2020, February 24). Barbuda Council asks DCA to issue stop order on PLH project. The Daily Observer. https://antiguaobserver.com/barbuda-council-asks-dcato-issue-stop-order-on-plh-project/

Joseph, C. (2020, March 25). Barbuda Council blocks Palmetto Point access. The Daily Observer. https://antiguaobserver.com/barbuda-council-blocks-palmetto-point-access-2/

Joseph, M. (1999). Nomadic identities: The performance of citizenship. University of Minnesota Press.

Kaenzig, R., \& Piguet, E. (2014). Migration and climate change in Latin America and the Caribbean. In E. Piguet \& F. Laczko (Eds.). People on the move in a changing climate (pp. 155-176). Springer. https://doi.org/10.1007/978-94-007-6985-4 7

Klein, N. (2007). The shock doctrine: The rise of disaster capitalism. Allen Lane.

Klein, N., \& Brown, A. (2018, January 23). Robert DeNiro accused of exploiting Hurricane Irma to build resort in Barbuda. The Intercept. https://theintercept.com/2018/01/23/robert-de-niro-barbuda-hotel-hurricane-irma/ 
Klein, N., \& Peet, R. (2008). The shock doctrine: The rise of disaster capitalism. Human Geography, 1(2), 130-133. https://doi.org/10.1177/194277860800100215

Knepper, W. (2006). Colonization, creolization, and globalization: The art and ruses of bricolage. Small Axe, 10(3), 70-86. https://doi.org/10.1215/-10-3-70

Look, C., Friedman, E., \& Godbout, G. (2019). The resilience of land tenure regimes during Hurricane Irma: How colonial legacies impact disaster response and recovery in Antigua and Barbuda. Journal of Extreme Events, 6(01), 1940004. https://doi.org/10.1142/S2345737619400049

Lowenthal, D., \& Clarke, C.G. (1980). Island orphans: Barbuda and the rest. Journal of Commonwealth \& Comparative Politics, 18(3), 293-307. https://doi.org/10.1080/14662048008447365

MacKay, J., Levin, J., de Carvalho, G., Cavoukian, K., \& Cuthbert, R. (2014). Before and after borders: The nomadic challenge to sovereign territoriality. International Politics, 51(1), 101-123. https://doi.org/10.1057/ip. 2013.24

Oviedo, G., \& Kenza Ali, M. (2018). The relationship of indigenous peoples and local communities with wetlands: An initial report. Ramsar.

Pearce, T., Ford, J., Willox, A.C., \& Smit, B. (2015). Inuit traditional ecological knowledge (TEK), subsistence hunting and adaptation to climate change in the Canadian Arctic. Arctic, 68(2), 233-245. https://doi.org/10.14430/arctic4475

Perdikaris, S., Bain, A., Grouard, S., Baker, K., Gonzalez, E., Hoelzel, A.R., Miller, H., Persaud, R., \& Sykes, N. (2018). From icon of empire to national emblem: new evidence for the fallow deer of Barbuda. Environmental Archaeology, 23(1), 47-55. https://doi.org/10.1080/14614103.2017.1349027

Perdikaris, S., Grouard, S., Hambrecht, G., Hicks, M., Mebane Cruz, A., \& Peraud, R. (2013). The caves of Barbuda's eastern coast: Long term occupation, ethnohistory and ritual. Caribbean Connections, 3, 1-9.

Perdikaris, S., \& Hejtmanek, K.R. (2020) The sea will rise, Barbuda will survive: Environment and time consciousness. Ecocene. Forthcoming.

Perdikaris, S., Hejtmanek, K., Boger, R., Ams, J. D., Potter, A.E., \& Mussington, J. (2013). The tools and technologies of transdisciplinary climate change research and community empowerment in Barbuda. Anthropology News, 54(2).

Phillips, Z.A.R. (2019). Barbuda's community title to land: A furtherance of the Convention on Biological Diversity?. Review of European, Comparative \& International Environmental Law, April, 118-128. https://doi.org/10.1111/reel.12305

Pickerill, J. (2018). Black and green: The future of Indigenous-environmentalist relations in Australia. Environmental Politics, 27(6), 1122-1145. https://doi.org/10.1080/09644016.2018.1466464

Potter, A.E. (2015a). "Fighting for the Rock at home and abroad": Barbuda Voice newspaper as a transnational space. Historical Geography, 43, 139-157.

Potter, A.E. (2011). Transnational spaces and communal land tenure in a Caribbean place: "Barbuda is for Barbudans." $\mathrm{PhD}$ dissertation, Louisiana State University, Department of Geography and Anthropology. 
Potter, A.E., \& Sluyter, A. (2010). Renegotiating Barbuda's commons: Recent changes in Barbudan open-range cattle herding. Journal of Cultural Geography, 27(2), 129-150. https://doi.org/10.1080/08873631.2010.494404

Raygorodetsky, G. (2018, November 16). Indigenous peoples defend Earth's biodiversitybut they're in danger. National Geographic. https://www.nationalgeographic.com/environment/2018/11/can-indigenous-landstewardship-protect-biodiversity-/\#close

Schuster, R., Germain, R.R., Bennett, J.R., Reo, N.J., \& Arcese, P. (2019). Vertebrate biodiversity on indigenous-managed lands in Australia, Brazil, and Canada equals that in protected areas. Environmental Science \& Policy, 101, 1-6. https://doi.org/10.1016/j.envsci.2019.07.002

Sluyter, A. (2012). Black ranching frontiers: African cattle herders of the Atlantic world, 1500-1900. Yale University Press. https://doi.org/10.12987/yale/9780300179927.003.0004

Tsing, A.L. (2011). Friction: An ethnography of global connection. Princeton University Press. https://doi.org/10.2307/j.ctt7s1xk

Tweedy, M.A. (1981). History of Barbuda under the Codringtons: 1738-1833. PhD Dissertation. University of Birmingham AL: Department of History.

United Nations High Commissioner for Refugees (2015). Report on guidance on protecting people from disasters and environmental change through planned relocation. United Nations High Commissioner for Refugees. https://www.unhcr.org/enus/protection/environment/562f798d9/planned-relocation-guidance-october2015.html

United Nations Permanent Forum on Indigenous Issues (n.d.). Indigenous peoples, Indigenous voices. United Nations Permanent Forum on Indigenous Issues.

Usher, P. J. (2000). Sacred knowledge, traditional ecological knowledge and resource management. Arctic, 53(2), 198-199. https://doi.org/10.14430/arctic887

Wolf, J., Allice, I., \& Bell, T. (2013). Values, climate change, and implications for adaptation: Evidence from two communities in Labrador, Canada. Global Environmental Change, 23(2), 548-562. https://doi.org/10.1016/j.gloenvcha.2012.11.007

Yacobi, H., \& Tzfadia, E. (2019). Neo-settler colonialism and the re-formation of territory: Privatization and nationalization in Israel. Mediterranean Politics, 24(1), 1-19. https://doi.org/10.1080/13629395.2017.1371900

Zarnoch, C.B., Hossain, N., Fusco, E., Alldred, M., Hoellein, T.J., \& Perdikaris, S. (2020). Size and density of upside-down jellyfish, Cassiopea sp., and their impact on benthic fluxes in a Caribbean lagoon. Marine Environmental Research, 154, 104845. https://doi.org/10.1016/j.marenvres.2019.104845 